\title{
17
}

\section{Living a Modern Life in Hokkaidō as a Young Ainu Dancer}

\author{
Mana Shinoda (translated by Hiroshi Maruyama)
}

I live in an Ainu village in Hokkaidō where a number of Ainu people once made their living by hunting, fishing and trading. I was born in 1987 to a Japanese mother and an Ainu father; my mother raised me as an ethnic Japanese. As time passed, I came to identify the Ainu-ness in my blood. Today, I spend time learning about Ainu traditional embroidery and manual work and make a living by performing Ainu traditional dance at the Ainu theatre 'Ikor' at Akan Lake in Kushiro. I have met some people who say that Ainu culture is dying, or who utter that there may not be any Ainu. They have the following assumptions: Ainu culture is a relic of the past; Ainu live in traditional houses and wear their traditional clothes and speak the Ainu language. Are those assumptions right?

\section{Is Ainu culture dying?}

\section{Transmitting Ainu clothes to the next generation}

Ainu clothes are made from different types of materials. They were once made from grass fibres, animal skins, fish skin and bark. In the Edo period, some of them were made from cotton, which came to the Ainu through trading with the Japanese. These cotton clothes were embroidered by women for generations to avert demons. They were used for clothing called 
ruunpe and chinjiri (see Figure 12). There are different Ainu embroidery patterns in each Ainu community. At present, we Ainu wear Western clothes on a daily basis as do the Japanese and we wear Ainu clothes for rituals and cultural gatherings. Thus, Ainu clothes have been transformed by Japan's colonisation of Hokkaidō and the assimilationist policy, but we Ainu did not lose our identity as Ainu people. We Ainu women have succeeded in transmitting the technique of making Ainu clothes and doing embroidery from mother to child at home and from other Ainu women, who have devoted themselves to preserving Ainu culture, in each community (see also Tsuda, Chapter 16).

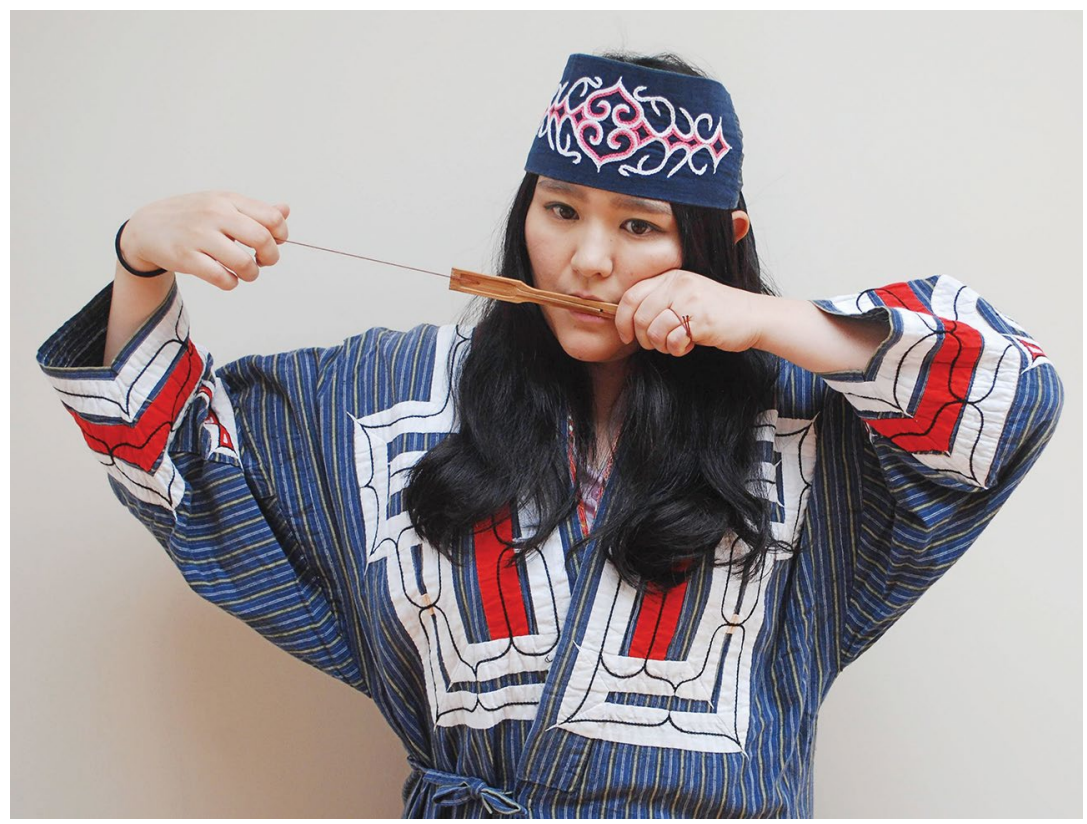

Figure 12. Mana Shinoda in a traditional Ainu dress, ruunpe, playing the mukkuri (Jews' harp).

Source. Photographed by Ryo Yonezawa at the Shiraoi office of the Foundation for Ainu People's Culture, 4 September 2018. Used with permission.

\section{Transmitting Ainu food to the next generation}

The Ainu once sustained their livelihood by hunting, gathering and fishing. They lived in the neighbourhood of a river, where salmon went upstream to spawn, and they farmed in some areas. The main crops of the Ainu included cereals such as Japanese millet, foxtail millet and soba, which were harvested by the slash-and-burn method. In Hokkaidō and 
the northernmost part of Honshu where they settled down, soil was fertile and food resources were abundant. Also, they survived the harsh winters by developing techniques to preserve deer meat, salmon and edible wild plants. In regard to today's diet, there seem to be no more than a few differences between what the Ainu and the Japanese eat. Nevertheless, our Ainu community sees that elderly women take a lead in cooking traditional food and making tonoto, or raw sake, for rituals. They teach their juniors these recipes and techniques while singing traditional songs all together. This spring, I was taught how to make potcheimo, dumplings made from potatoes that fermented in winter, by a fuchi, or female elder. It takes time for us to make or cook any Ainu cuisine, which is closely associated with nature. Whenever going into the mountains to harvest edible wild plants in early spring, we say our prayers to the gods of the mountains for sharing the blessings of nature with the gods. The most well-known Ainu ritual for harvest is Asircepnomi, which is performed when salmon begin going upstream in a river. This ritual helps us to hand down our concept that we are part of nature and that we have to take wildlife in gratitude. This should be kept in mind among us.

\section{Transmitting Ainu architecture to the next generation}

We Ainu call our residence chise. The traditional residence of the Ainu is a plain dwelling that was shifted from a pit dwelling in the thirteenth century. Also, it was made from local trees and plants, and thus differed in structure to some extent from area to area. Many researchers write that the Ainu set up windows in the east side of their residence as the east is sacred for the Ainu, but this is not universally true. Such residences were seen only in Nibutani. However, without exception, any chise has an apeoi or a sunken fireplace in the centre. In Ainu society, there is a custom of keeping a fire in the sunken fireplace throughout a year. The Ainu have valued fire as a god named Apefuchi kamui, meaning fire in elderly woman form, more highly than other gods in relation to life. Fire is considered to essentially support the lives of the Ainu who traditionally lived in the cold districts, including Hokkaidō, Sakhalin and the Kuril Islands. Since the Ainu do not directly address their gods, Apefuchi kamui is thought to mediate between the Ainu and the gods. That is why Ainu rituals begin with asking Apefuchi kamui to listen to Ainu's prayers and to convey them to other gods. This Ainu traditional belief convinces me that the Ainu originally had no notion of male superiority. Unfortunately, the assimilationist policy toward the Ainu under Japan's colonisation of 
Hokkaidō prohibited the Ainu from building traditional chise. As a result, no Ainu live in traditional chise today. Nevertheless, rituals in relation to residence, including Chise koenomi - the ceremony of purifying a building site- and Chise inomi - the ceremony to celebrate the building of a new house- have been passed down unbroken from generation to generation.

\section{Taking a first step beyond the profession as a performer of Ainu traditional dance}

In February 2015, the Association of Ainu Youth was established by the Ainu themselves as the first nationwide Ainu organisation, following the example of the Finnish Sami Youth Organisation. The association aims to promote Ainu culture and international exchange programs with other Indigenous peoples. Since the outset, as a board member, I have been involved in making arrangements to carry out a movie event and a seminar on the history of the Ainu. In April 2015, I had the opportunity to address a session of the United Nations Permanent Forum on Indigenous Issues, and I also made a presentation on the status quo of the Ainu at a meeting with Victoria Tauli-Corpuz, the special rapporteur on the rights of Indigenous peoples. The theme of the session was 'Human Rights: The implementation of the UN Declaration on the Rights of Indigenous Peoples'. Below is the text of my address.

Thank you, Chairperson. Irankarapute (Hello)

My name is Mana Shinoda. I am Ainu, an Indigenous people in Japan.

I perform Ainu songs and dances handed down from our ancestors with a traditional Ainu dress, ruunpe, at Japan's only traditional Ainu dance theater every day. Fortunately, this is my job. Why did I just say 'fortunately'? Because it is not usual nowadays that the Ainu engage in transmission and protection of our own culture for a living in Japan. Most Ainu people have ordinary jobs like other Japanese. Some of them live and work without ever telling their identity as Ainu. One of the reasons why some Ainu hide their identity must be reflected by negative speech against Ainu. Last year, a Japanese politician said, 'The Ainu people do not exist anymore'. Another politician also said, 'It is doubtful that the Ainu are indigenous'. These statements are obviously hate speech and violate our right not to be subjected to forced assimilation under Article 8 of UNDRIP [United Nations Declaration on the Rights of Indigenous Peoples]. The Japanese Government has an obligation to take effective measures to combat such prejudice and eliminate discrimination under Article 15 of UNDRIP 
and other human rights treaties. However, the Japanese Government has not taken such measures. Moreover, a description of the Ainu history was recently revised from 'the Government dispossessed the lands of the Ainu people' to 'the Government gave the lands to the Ainu people' in the process of the textbook examination of the Ministry of Education. The new description introduces a discriminatory law, the Hokkaidō Former Aborigines Protection Act, in a positive context, which leads to misconceptions. This revision clearly violates our right to transmit our histories under Article 13 of UNDRIP. Histories of indigenous peoples shall be appropriately reflected in education under Article 15 of UNDRIP and other human rights treaties.

Recommendation: The Japanese Government should immediately take measures against hate speech and conduct education in which children can learn the histories of indigenous peoples properly. Iyairaikere (Thank you).

The session spared a long time for discussions on Indigenous women who have suffered from double discrimination. What interested me was a speech made by an elderly woman from an Indigenous people in Russia. She said that half of the leaders of Indigenous peoples in Russia are women and that customs of excluding women are not worth cultural transmission. Unfortunately, Russia seems to be an exception in terms of women's leading role in Indigenous peoples. In the case of the Ainu, women disproportionally bear a burden in domestic work and child rearing, in addition to embroidering and performing traditional songs and dances. It must be affected by some bad practices from Japanese society. In order to make a breakthrough in the situation, I hope the Japanese Government and municipalities will provide an appropriate environment for those Ainu women who intend to be involved in activities for cultural transmission and the improvement of their status. It is good not only for Ainu women but also for Japanese women. Further, those who addressed me in the headquarters of the United Nations in New York were non-Japanese, not Japanese. I came to know that we Ainu should make efforts to encourage the dissemination of the existence of ourselves among Japanese people. Also, I recognised again how important it is to deepen communications with other Indigenous peoples via international conferences and the internet. Academic research does not deal with all aspects of Ainu culture. The Ainu themselves, therefore, should strive to transmit our material and spiritual assets to future generations. Ainu culture is not dying. It is always changing, and extending to new genres of music and art. 
INDIGENOUS EFFLORESCENCE

\section{Reference}

United Nations Declaration on the Rights of Indigenous Peoples, GA Res 61/295, UN GAOR, 61st sess, 107th plen mtg, Sup No 49, UN Doc A/RES/61/295 (13 September 2007). 
This text is taken from Indigenous Efflorescence: Beyond Revitalisation in Sapmi and Ainu Mosir, edited by Gerald Roche, Hiroshi Maruyama and Åsa Virdi Kroik, published 2018 by ANU Press, The Australian National University, Canberra, Australia.

doi.org/10.22459/IE.2018.17 